\title{
KEBIJAKAN UMKM NURIZA SNACK DALAM MENINGKATKAN PRODUKTIVITAS, EFISIENSI DAN PENDAPATANNYA
}

\author{
Dian Sabrina Syaharni ${ }^{1}$, Erika Gustian $\mathrm{F}^{2}$, Salsabillah Sirait ${ }^{3}$ \\ ${ }^{1}$ Program Studi Manajemen, Fakultas Ekonomi , Universitas Internasional Batam \\ 2 Program Studi Manajemen, Fakultas Ekonomi , Universitas snternasional Batam \\ ${ }^{3}$ Program Studi Manajemen, Fakultas Ekonomi , Universitas Internasional Batam \\ 2041257.dian@uib.edu¹,2041258.erika@uib.edu²,204125.salsabillah@uib.edu³
}

\begin{abstract}
ABSTRAK
Nuriza Snack adalah badan usaha yang bergerak dibidang makanan ringan skala mikro kecil dan menengah. UMKM ini mengalami performa yang kurang baik dalam proses bisnis. Dimasa pandemi terjadi penurunan omzet yang signifikan dan menyebabkan UMKM ini mengalami kerugian. Untuk itu diperlukan adanya strategi penerapan kebijakan atau prosedur baru untuk meningkatan produktivitas, efisiensi, dan pendapatannya. Tujuan dari penelitian ini yaitu untuk menganalisis permasalahan yang dihadapi UMKM dan membuat kebijakan yang dapat dilakukan UMKM Nuriza Snack. Pada penelitian ini, metode yang digunakan yaitu wawancara dan mengobservasi keadaan UMKM tersebut sehingga didapatkan data yang digunakan sebagai penunjang dalam penelitian ini. Hasil dari penelitian ini yaitu UMKM Nuriza Snack perlu melakukan inovasi dari aspek proses bisnis yang dijalankan dengan meningkatan kebijakan yang dibuat. Dengan adanya penelitian ini, UMKM ini diharapkan dapat meningkatkan efektivitas kinerja dari karyawan maupun dari pimpinan dalam melaksanakan kebijakan - kebijakan sehingga tercipta peningkatan dalam proses bisnis.
\end{abstract}

Kata Kunci: Pengelolaan UMKM, Kebijakan bisnis, Peningkatan, Proses Bisnis,

\begin{abstract}
Nuriza Snack is a business entity engaged in snacks. SMES experience a lack of effectiveness in business processes. In the pandemic decline in turnover is a significant cause of SMES is experiencing a loss. It is necessary for a policy or a new procedure in increasing productivity, efficiency, and revenue. The purpose of this study is to analyze the problems that diahadapi SMES and creating policies that can be done SMES Nuriza Snack. In this study, the methods used are interviews and observe the state of the SMES so that the data obtained are used as a support in this research. The results of this study, namely SMES Nuriza Snack need to make improvement from the aspects of the business process by improving the policies that are made. With this research, is expected to improve the effectiveness of the performance of the employees and from the leadership in implementing policies so that the creation of an improvement in business processes.

Keywords:SMES Management, business policy, Improvement,BusinessProcess,
\end{abstract}




\section{PENDAHULUAN}

Perusahaan atau organisasi bisnis memiliki kebijakan dalam menjalankan aktivitasnya. Kebijakan ini didasari pada visi dan tujuan yang ingin dicapai. Di dalam sebuah perusahaan atau industri tentu memiliki prinsip untuk selalu maju kedepan dengan harapan adanya peningkatan produktivitas, efisiensi dan pendapatan di setiap periodenya (Elisabet, 2012). Semua kegiatan didalam perusahaan harus dikelola dengan baik, mulai dari produksi, distribusi, sampai dengan manajemen. Untuk itu butuh adanya Sumber Daya Manusia yang berkualitas untuk dapat mengelola perusahaan sehingga dapat berjalan efektif dan efisien.

Memasuki era Society 5.0 dimana bisnis didukung oleh teknologi modern dan memudahkan para pelaku usaha dalam operasionalnya. Banyak perusahaan (start up) yang didirikan sejak dua dasawarsa terakhir, dimana perusahaan ini lebih mengedepankan adanya penyediaan produk dan layanan yang begitu cepat(Ryan et al., 2017). Dukungan ini ditandai dengan adanya mobilitas masyarakat dijagad digital. Tentu saja ini menjadi peluang besar bagi pelaku usaha untuk menciptakan inovasi dalam bisnis. Untuk itu berbagai strategi dan kebijakan dibuat dengan tepat sasaran agar usahanya dapat maju dan berkembang (Falahah, 2012).

Usaha Mikro, Kecil, Menengah (UMKM) adalah salah satu pelaksana ekonomi yang mempunyai peran, tempat, dan kontribusi yang dapat mempengaruhi perekonomian di
Indonesia karena bersifat mudah dalam menjalankan dan beradaptasi adanya perubahan pada pasar. Dan juga, UMKM berperan dalam pengadaan lapangan pekerjaan karena mampu merekrut calon pekerja dan penanaman modal dengan jumlah yang tidak begitu besar. Umumnya UMKM memiliki kelebihan dalam memanfaatkan sumber daya alam dan sektor lainnya. Saat ini, semakin banyak para pengusaha UMKM di Indonesia, sehingga diperlukan langkah dan upaya yang positif untuk mendukung para pelaku usaha dalam meningkatkan perkembangan usaha mereka.

Tidak sedikit pelaku usaha UMKM yang masih belum mengetahui strategi untuk mengingkatkan usaha mereka dalam hal perencanaan, produksi, dan pemasaran yang belum bisa mencapai sasaran. Para pelaku usaha diperlukan adanya pemberian pengetahuan dasar terkait permasalahan yang sering muncul dalam usaha mereka. Untuk itu, adanya peran penting pemerintah dalam peningkatan ekonomi, yang dapat dilihat dalam program kerja yang menggerakkan keseluruh sektorperekonomian (Coulthard et al, 1996). Para pelaku UMKM dan pemerintah turut bekerja sama dalam meningkatkan eksistensi mereka agar dapat memperbaiki dan menanggulangi permasalahan yang sering terjadi di aspek perencanaan, produksi, hingga pemasaran yang tepat.

Nuriza Snack adalah badan usaha yang bergerak dibidang makanan ringan. Nuriza Snack 
ini merupakan UMKM ini berlokasi di Perumahan GMP Tahap 2 Tanjung Sengkuang, Batam. UMKM ini didirikan oleh Ibu Partin pada tahun 1994 dan masih beroperasi sampai sekarang. Pemilik mendirikan UMKM ini dikarenakan dulunya mengalami kesulitan dalam bidang ekonomi. Pada saat itu masih jarang masyarakat yang membuka usaha produksi keripik sehingga pemilik berinisiatif untuk berwirausaha keripik ini. Pada awal penjualan, pemilik UMKM ini menitipkan produknya ke warung-warung kecil disekitar lokasi UMKM berdiri dengan pendapatan sebesar Rp 50.000 per minggu. Selang beberapa tahun yaitu pada tahun 2007 pemilik UMKM mengembangkan usahanya lebih giat lagi dan berhasil mendistribusikan produknya di sejumlah mal yang ada di Kota Batam. Ketika menjalankan usaha tentu terdapat beberapa permasalahan yang dihadapi misalnya dalam hal produktivitas, efisiensi, dan pendapatan, apalagi UMKM Nuriza Snack telah beroperasi selama 27 tahun. Dalam hal produktivitas, UMKM ini dapat dikatakan cukup baik. Setelah produk tersebut berhasil didistribusikan ke pusat-pusat perbelanjaan, pendapatan yang diperoleh UMKM ini pun meningkat pesat berkisar 30-40 juta per bulan. Namun, semenjak pandemi Covid-19 omzet UMKM Nuriza Snack mengalami penurunan. Kondisi ini memberikan perhatian khusus bagi pemilik dan juga didukung oleh hasil penelitian lainnya bahwa di era new normal sangat penting untuk merancang strategi bisnis dan merumuskan kebijakan, meningkatkan efisiensi dalam kegiatan operasional hingga dapat meningkatkan laba sesuai dengan tujuan perusahaan.

Gambar.1 Omzet Pendapatan UMKM Nuriza Snack pada Bulan April - September 2020

\begin{tabular}{|c|c||c|}
\hline No & Bulan & Jumlah Omzet \\
\hline \hline 1 & April & Rp 35.000.000;- \\
\hline 2 & Mei & Rp 31.000.000;- \\
\hline 3 & Juni & Rp 30.000.000;- \\
\hline 4 & Juli & $R p ~ 26.000 .000 ;-$ \\
\hline 5 & Agustus & $R p 24.000 .000 ;-$ \\
\hline 6 & September & $R p 21.000 .000 ;-$ \\
\hline
\end{tabular}

Gambar.2 Grafik Omzet

\section{Grafik Omzet}

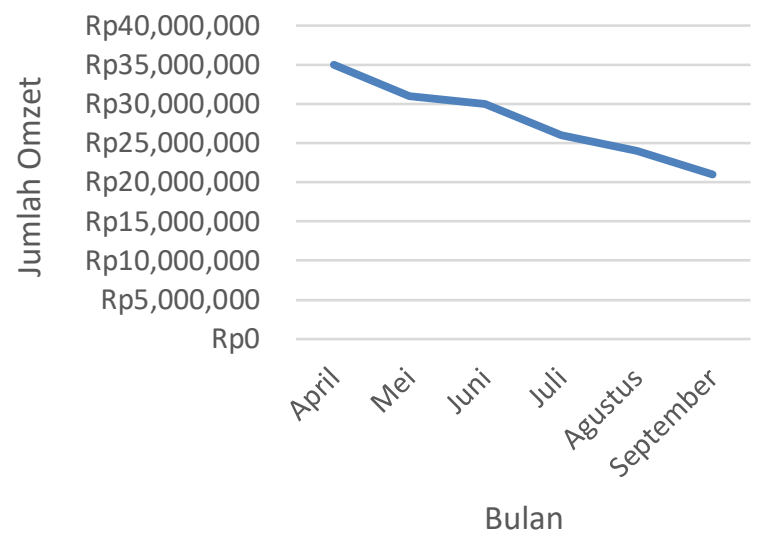

Penulisan artikel ini bertujuan untuk Menganalisis permasalahan yang dihadapi pada UMKM Nuriza Snack dan membuat kebijakankebijakan yang dapat dilakukan UMKM Nuriza Snack untuk menangani permasalahan yang dihadapi. Manfaat dari penelitian ini yaitu menjadi bahan referensi bagi UMKM dalam meningkatkan produktivitas, efisiensi, dan pendapatan usahanya, mengetahui kebijakankebijakan yang dapat dilakukan oleh UMKM dalam meningkatkan produktivitas, efisiensi, dan pendapatan usahanya, menambah pengetahuan terkait cara menghadapi 
permasalahan yang terjadi, sebagai bahan acuan/penelitian untuk penelitian selanjutnya.

Proses bisnis merupakan kegiatan atau pekerjaan yang disusun dan saling berkaitan untuk menyelesaikan suatu masalah atau menghasilkan produk atau jasa untuk mencapai tujuan tertentu. (Davenport, 1994), menyatakan bahwa proses bisnis merupakan kegiatan yang terencana dan terukur untuk menciptakan output tertentu sesuai dengan pelanggan yang dituju. Dari pengertian tersebut dapat disimpulkan bahwa proses bisnis merupakan kegiatan yang dilakukan untuk pengadaan atau memproduksi suatu produk maupun jasa yang bermanfaat dan bernilai bagi pelanggan.

Proses bisnis dibangun untuk menciptakan langkah- langkah kerja dari pengolahan produk belum jadi hingga menjadi produk atau jasa yang siap dipasarkan. Langkah - langkah kerja yang dilakukan merupakan gambaran dari kegiatan yang harus dilakukan untuk mencapai sasaran yang ditujukan. Proses bisnis yang baik memerlukan tujuan - tujuan yang jelas seperti keefektifan, keefisienan, dan membuat mudah proses didalamnya. Dengan begitu suatu proses bisnis harus mengarah kepada quantity dan kualitas dari produk yang dihasilkan.

Proses bisnis yang efektif dan efisien dapat menumbuhkan rasa kompetitif bagi perusahaan. Proses bisnis yang dijalankan dengan baik dapat menciptakan peluang. Namun suatu perusahaan belum mengetahui atau sadar dalam pengontrolan proses bisnis yang dijalankan. Apabila suatu proses bisnis memiliki kendala dan pengontrolan tidak dapat dilakukan, maka perusahaan tidak dapat mencapai sasaran yang akan dicapai.

Berdasarkan fungsinya, proses bisnis perusahaan yang memproduksi dan menjual produk memiliki proses bisnis yang mengikutsertakan pemasaran dan penjualan, produksi, keuangan dan sumber daya manusia yang melaksanakan fungsi-fungsi seperti :

1. Pemasaran dan penjualan produk, pempromosian produk melalui iklan, meperkirakan jumlah penjualan, berhubungan baik dengan pelanggan, melayani pelanggan dengan baik.

2. Pada bidang produksi dapat mengembangkan proses produksi lebih tertata, pegorderan bahan baku, memproduksi bahan baku, dan memasarkan prduk yang dihasilkan.

3. Bagian keuangan melakukan pencatatan serta pengelolaan keuangan perusahaan.

4. Merekrut sumber daya manusia yang sesuia dengan skill yang dimiliki dan memberikan kompensasi karyawan, perlindungan kepada karyawan, serta mengontrol kepatuhan terhadapat peraturan - peraturan yang dilakukan oleh karyawan.

Melaksanakan proses bisnis yang tepat bagi UMKM dapat mempermudah mereka dalam pengoprasionalan usaha untuk dapat bersaing 
dengan kompetitor lain. Pengetahuan cara penanggulangan permasalahan yang muncul pada proses bisnis seperti aspek perencanaan, produksi dan pemasaran. Perencanaan bisnis merupakan kegiatan suatu organisasi atau individu dalam mencapai tujuan di masa depan yang menyatukan berbagai aspek di perusahaan (Coulthard, Max, Andrea Howell, 1996). Perencanaan dalam bisnis memuat aspek aspek yang berhubungan dengan target, aktivitas yang dijalankan, dan fokus terhadap kekuatan untuk mencapai target yang dituju (Small business management: an entrepreneur's guide to success, 1993). Perencanaan dilaksanakan secara konsisten akan mempengaruhi keefektifan dari perencanaan dalam suatu usaha. Proses produksi ialah aktivitas yang menghasilkan produk atau jasa, dan aktivitas lain untuk menunjang usaha dalam menghasilkan barang atau jasa(Assauri, 2008). Dari pengertian diatas dapat disimpulkan bahwa proses produksi merupakan kegiatan menghasilkan produk atau jasa. Keberhasilan pembuatan produk yaitu bergantung pada prosedur pelaksanaan proses produksi di perusahaan tersebut. Jika prosedur pelaksanaan produksi baik, maka pelaksanaan prosedur tersebut dapat berhasil dan target produksi suatu produk tercapai sesuai dengan target yang ditentukan dan dengan kualitas yang baik, dan begitu sebaliknya. Agar hal tersebut tidak terjadi, maka dapat dilakukan pengaturan dalam produksi. Pengaturan ini dilakukan untuk menjamin produksi yang direncanakan sesuai dengan yang diharapkan. Proses pemasaran menurut (Kotler, 1973) yaitu aktivitas dalam pemenuhan kebutuhan dan keinginan manusia melalui proses perpindahan. Pemasaran merupakan proses dari aktivitas bisnis yang dibuat untuk mendesain, menentukan tarif, melakukan promosi, dan penyaluran produk produk yang dapat memberikan kepuasan kepada pelanggan sesuai dengan sasaran pasar(Kotler, Philip, 2007). (Kotler, Philip; Armstrong, 2008) menyatakan bahwa Prinsip dari pemasaran yaitu kebutuhan atau keinginan, permintaan, produksi, utilitas, nilai dan kepuasan,pemasaran, dan pasar. Dalam proses pemasaran, sasaran pasar harus tepat dan sesuai dengan target yang ditujukan untuk keberhasilan produk dalam mencapai target yang maksimal. Promosi pun turut andil dalam keberhasilan proses pemasaran. Promosi yaitu kegiatan yang dilakukan oleh suatu perusahaan dalam menawarkan atau mengenalkan produk atau jasa dengan tujuan untuk mendorong calon konsumen agar melakukan pembelian. Dengan melakukan promosi, perusahaan mengharapkan adanya kenaikan penjualan. Menurut (Sistaningrum, 2002) definisi promosi yaitu usaha atau aktivitas organisasi untuk mendorong "konsumen aktual" dan "pengguna potensial" supaya konsumen tersebut mau melaksanakan transaksi akan produk yang dijajakan saat ini atau diwaktu selanjutnya. Konsumen aktual merupakan konsumen yang langsung berbelanja barang yang ditawarkan pada saat atau sesudah promosi barang tersebut 
dilakukan oleh perusahaan. Sedangkan konsumen potensial merupakan konsumen yang tergiring untuk 15 melaksanakan pembelian akan barang yang ditawarkan oleh perusahaan di saat yang akan tiba. Pengertian promosi bagi (Moekijat, 2000)yaitu aktivitas suatu organisasi untuk memajukan perdagangan dengan memusatkan komunikasi dan kontak yang meyakinkan kepada para calon pengguna. Dari pengertian ahli diatas dapat diambil kesimpulan bahwa promosi merupakan kegiatan untuk menawarkan atau memperkenalkan produk kepada calon konsumen dengan tujuan untuk membujuk konsumen agar melakukan pembelian sehingga terjadi kenaikan angka penjualan

\section{METODE}

Penyusunan artikel ini menggunakan pendekatan kualitatif. Dalam penelitian ini, peneliti mengamati kondisi dari UMKM Nuriza Snack untuk mengetahui kebijakan apa yang tepat dalam menyelesaikan permasalahan yang dihadapi. Lokasi penelitian ialah lokasi dimana untuk mendapatkan informasi tentang data-data yang dibutuhkan. Dalam pemilihan lokasi penelitian,adanya keharusan mempertimbangkan ketertarikan, ciri-ciri, dan kesamaan dengan subyek yang dipilih. Lokasi yang dipakai dalam penelitian ini adalah UMKM "Nuriza Snack" yang beralamat di Perumahan GMP Tahap 2 Tanjung Sengkuang, Batam

Selain itu, teknik pengumpulan data digunakan dengan melakukan pengamatan langsung pada objek guna memperoleh data (Sugiyono, 2013). Pada tahap ini, teknik yang dilakukan yaitu mengobservasi UMKM Nuriza Snack dalam Pengoprasionalan untuk mengumpulkan data- data dari UMK Nuriza Snack yang berkaitan dengan permasalahan yang dihadapi. Kemudian, wawancara yang dilakukan kepada pihak UMKM Nuriza Snack yaitu Ibu Partin pemilik langsung dari UMKM tersebut secara langsung untuk mengetahui hal - hal yang lebih spesifik mengenai produktivitas, efisiensi, dan pendapatan.

Sumber data dalam penelitian merupakan dari mana data atau informasi tersebut didapatkan oleh peneliti dan cara pengambilan data yang diperoleh. Dalam penelitian ini, sumber data yang digunakan yaitu data primer dan sekunder. Untuk data primer, infromasi diperoleh dari hasi wawancara dengan narasumber UMKM Nuriza Snack. sedangkan data sekunder bersumber dari literarur, jurnal terdahulu, buku - buku, dan dokumen.

\section{HASIL DAN PEMBAHASAN}

Dalam menghasilkan produk makanan ringan berupa keripik, ada beberapa pihak yang terlibat baik pihak eksternal maupun pihak internal. Untuk pihak eksternal yang dimaksud adalah bahan baku (singkong, pisang, tempe, sukun, dlI). Pemasok atau disebut juga supplier adalah kelompok atau individu yang berperan sebagai penyedia bahan baku yang dibutuhkan oleh pelanggan atau customer mereka untuk memproduksi suatu produk dan jasa. Dari 
pengertian tersebut dapat diketahui bahwa supplier ini berperan sebagai penyedia bahan baku yang akan diproses menjadi keripik pada UMKM ini. Supplier tersebut merupakan pihak yang diajak kerjasama oleh UMKM Nuriza Snack setelah melalui beberapa tahap seleksi yang dilakukan. Sementara untuk pihak internal yang terkait adalah karyawan yang bertugas dalam hal pengupasan, pemotongan, penggorengan, serta pengemasan.

Berikut ini merupakan proses dalam menjalankan bisnis pada UMKM Nuriza Snack:

\section{Proses Perencanaan}

UMKM Nuriza Snack mempersiapkan beberapa hal yang diperlukan sebelum proses produksi dilakukan. Pada proses ini, biaya yang akan dikeluarkan untuk pembelian bahan baku dan bahan penunjang lainnya diperhitungkan dan dicatat pada buku kas. Biaya yang dikeluarkan tergantung dengan seberapa banyak permintaan (demand) akan produk tersebut.

2. Proses Produksi

Setiap harinya, UMKM Nuriza Snack mampu memproduksi keripik hingga 200 kilogram. Dimana jumlah produksi keripik bergantung pada jumlah permintaan (demand) saat itu. Proses produksi dilakukan oleh 10 orang karyawan yang masing-masing bertanggung jawab atas tugasnya. UMKM Nuriza Snack menerapkan sistem pemesanan PO (Pre-Order) maupun ready stock yang dapat dipesan melalui whatsapp dan instagram ataupun datang langsung ke rumah produksi. Pemesanan dengan sistem Pre-Order biasanya dilakukan oleh customer yang membeli dalam kuantitas besar. Sedangkan pemesanan melalui sistem ready stock biasanya dilakukan oleh customer yang membeli dalam kuantitas kecil.

3. Proses Pemasaran

Dalam hal pemasaran, UMKM Nuriza Snack mendistribusikan produkproduknya pada beberapa pasar swalayan yang ada di Kota Batam. Selain itu, UMKM ini memanfaatkan media sosial Whatsapp dan Instagram. Hal ini dilakukan demi mempermudah customer yang akan membeli secara online tanpa harus mendatangi pasar swalayan dimana produk hasil produksi UMKM ini dijual ataupun ke rumah produksi.

Setiap usaha tentu selalu berharap untuk dapat meminimalisir terjadinya permasalahan dalam suatu data ataupun kegiatan. Permasalahan tersebut dapat menyebabkan terjadinya penurunan produktivitas, efisiensi, dan pendapatan. Untuk dapat terus meningkatkan produktivitas, efisiensi dan pendapatan tentu perlu adanya kebijakan-kebijakan yang dilakukan. Berbagai kebijakan yang dapat dilakukan untuk mengatasi permasalahan yang telah dipaparkan antara lain 
adalah dengan menerapkan pencatatan keuangan secara digital. Digitalisasi pencatatan penting dilakukan karena lebih aman, dapat melakukan pengawasan keuangan lebih mudah dari mana saja dan kapan saja, dan pencatatan rapi sehingga menghindari terjadinya kerugian akibat pencatatan data tidak tercatat dengan rapi.

Menurunnya produktivitas usaha juga dapat disebabkan oleh ketidaksiplinan karyawan dalam bekerja. Untuk itu, sebuah usaha yang memiliki permasalahan ini khususnya UMKM Nuriza Snack perlu membuat peraturan tegas dan memberikan sanksi apabila melanggarnya. SOP (Standar Operasional Prosedur) juga perlu disusun dan diterapkan demi tetap terkendalinya produktivitas dan kinerja karyawan dalam usaha ini. Tidak hanya itu, meningkatkan kinerja karyawan juga dapat dilakukan dengan memberikan bonus atau reward kepada karyawan. Adanya pemberian bonus atau reward akan memotivasti karyawan untuk bekerja lebih baik lagi.

Gambar.3 pengemasan Produk

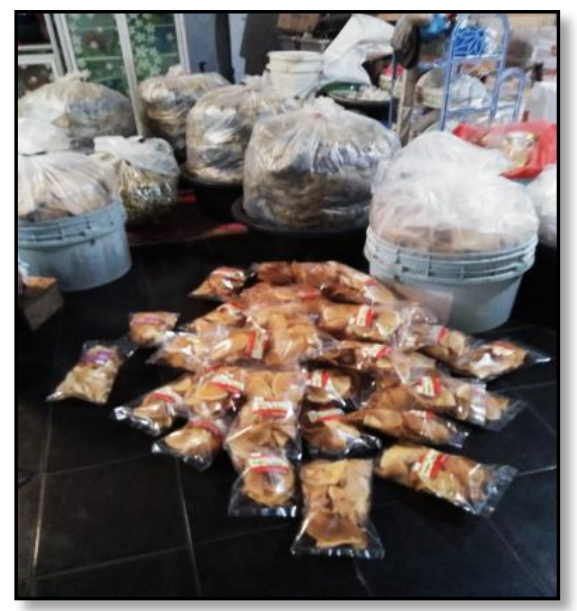

UMKM Nuriza Snack masih menggunakan kemasan produk berbahan dasar plastik. Oleh karena itu, perlu adanya kebijakan untuk mengatasi permasalahan yang tidak baik untuk lingkungan itu. Kebijakan yang dapat dilakukan adalah mengganti kemasan produk yang berbahan plastik dengan kemasan produk berbahan kertas. Kemasan berbahan dasar kertas lebih ramah lingkungan. Hal ini kurang baik dilakukan guna mengurangi penggunaan plastik yang terus meningkat jumlahnya.

Gambar.4 Kemasan yang masih berbahan dasar Plastik

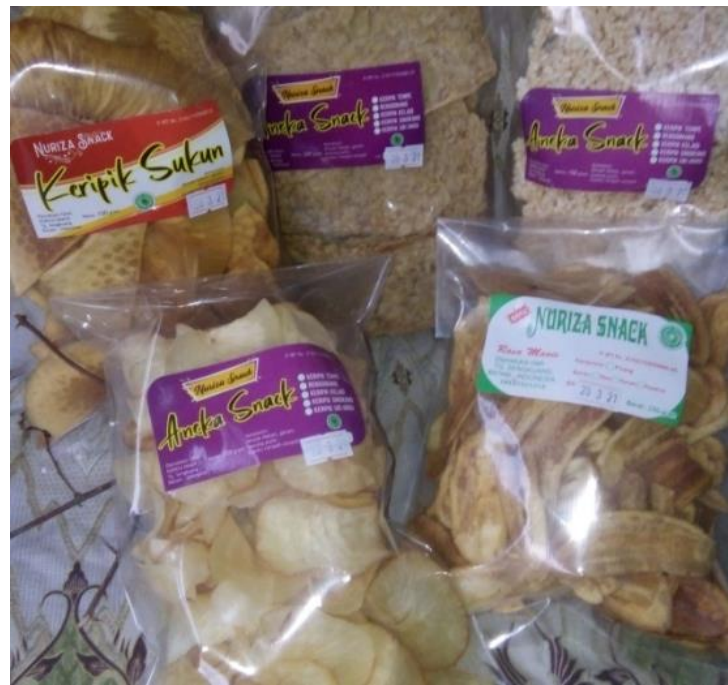

Dalam hal mengatasi permasalahan pada proses pemasaran, kebijakan yang dapat dilakukan oleh UMKM Nuriza Snack adalah dengan mencoba memasuki pasar internasional khususnya Singapura dan Malaysia. Peluang kesuksesan distribusi produk makanan ringan berupa keripik ke luar negeri dipastikan lebih besar dari pada didistribusikan ke luar kota. Hal ini dikarenakan tidak banyaknya kompetitor yang menjual produk yang sama disana. Produk kripik hasil produksi UMKM Nuriza Snack juga 
dapat dijual dengan harga yang lebih tinggi di luar negeri. Dengan begitu, tentu akan meningkatkan pendapatan UMKM ini.

UMKM Nuriza Snack juga dapat menjual produk hasil produksinya ke luar kota jika ingin. Akan tetapi, ada baiknya untuk UMKM menciptakan inovasi atau variasi baru pada produk keripiknya. Misalnya dengan menambah variasi rasa baru yang belum pernah dibuat oleh kompetitor di luar kota khususnya. Adanya variasi rasa baru yang belum pernah ada tersebut akan membuat konsumen di kota tersebut penasaran dan membelinya. UMKM Nuriza Snack mencari beberapa distributor dari luar kota yang dapat mendistribusikan produk keripik hasil produk UMKM ini. Apabila produk keripik dengan varian rasa baru yang belum pernah dijual kompetitor tersebut disukai dan laku oleh masyarakat luar kota, maka UMKM Nuriza Snack memiliki peluang yang bagus di luar kota dan dapat menyaingi kompetitor yang ada. Kebijakan lainnya yaitu dengan menetapkan harga promosi seperti Buy 3 Get 1 dan bundle pricing. Dengan begitu customer akan tertarik dan rela untuk membeli lebih banyak produk. Hal ini juga akan menjadi faktor bertambahnya pendapatan pada UMKM ini. Pendapatan yang meningkat tentu menjadi tujuan dan suatu kebanggaan ketika menjalankan usaha.

\section{PENUTUP}

\section{Kesimpulan}

Berdasarkan hasil penelitian diatas maka dapat ditarik kesimpulan bahwa UMKM Nuriza Snack merupakan salah satu UMKM di Kota
Batam yang bergerak di bidang kuliner. produksi, hingga pemasaran yang tepat. UMKM Nuriza Snack berlokasi di Perumahan GMP Tahap 2 Tanjung Sengkuang, Batam. UMKM ini didirikan oleh Ibu Partin pada tahun 1994 dan masih beroperasi sampai sekarang. UMKM ini telah beroperasi selama kurang lebih 27 tahun dan tentunya sudah banyak menghadapi berbagai permasalahan yang mengakibatkan ketidakstabilan produktivitas, efisiensi, dan pendapatan khususnya pada saat pandemi Covid-19. Proses bisnis yang dijalankan oleh UMKM ini yaitu dari proses perencanaan hingga proses pemasaran produk. Pada proses perencanaan, permasalahan yang dihadapi yaitu dalam hal Pencatatan keuangan usaha masih dilakukan secara tradisional dengan media pembukuan. Hal tersebut membuat pencatatan menjadi kurang efektif, dikarenakan kurangnya ketelitian dalam perhitungan pemasukan dan pengeluaran. Untuk itu dengan dilakukan pencatatan keuangan secara digital melalui aplikasi Microsoft Excel misalnya, dapat membuat pencatatan menjadi jelas dan mudah dipahami. Untuk permasalahan pada produksi, UMKM Nuriza Snack masi terkendala dalam pengadaan bahan baku. Kelangkaan bahan baku terkadang meenjadi penyebab dalam permasalahan produksi. Selain itu, kurangnya kedisiplinan tenaga kerja dan penggunaan packaging yang masih berbahan dasar plastik yang kurang ramah lingkungan. Kedisiplinan karyawan juga menjadi perhatian dalam pengoprasian usaha. Untuk itu perlunya 
pengetahuan peraturan dasar di setiap persusahaan dan meningkatkan kinerja karyawan juga dapat dilakukan dengan memberikan bonus atau reward kepada karyawan. Adanya pemberian bonus atau reward akan memotivasti karyawan untuk bekerja lebih baik lagi. Permasalahan pada kemasan berbahan plastik, hal tersebut masih menjadi perhatian untuk UMKM ini. Kebijakan yang dapat dilakukan adalah mengganti kemasan produk yang berbahan plastik dengan kemasan produk berbahan kertas. Kemasan berbahan dasar kertas lebih ramah lingkungan. Hal ini kurang baik dilakukan guna mengurangi penggunaan plastik yang terus meningkat jumlahnya. Untuk mengatasi permasalahan pada proses pemasaran, kebijakan yang dapat dilakukan oleh UMKM Nuriza Snack adalah dengan mencoba memasuki pasar internasional khususnya Singapura dan Malaysia. Peluang kesuksesan distribusi produk makanan ringan berupa keripik ke luar negeri dipastikan lebih besar dari pada didistribusikan ke luar kota. Hal ini dikarenakan tidak banyaknya kompetitor yang menjual produk yang sama disana. Produk kripik hasil produksi UMKM Nuriza Snack juga dapat dijual dengan harga yang lebih tinggi di luar negeri. Dengan begitu, tentu akan meningkatkan pendapatan UMKM ini. UMKM Nuriza Snack juga dapat menjual produk hasil produksinya ke luar kota jika ingin. Akan tetapi, ada baiknya untuk UMKM menciptakan inovasi atau variasi baru pada produk keripiknya. Misalnya dengan menambah variasi rasa baru yang belum pernah dibuat oleh kompetitor di luar kota khususnya. Adanya variasi rasa baru yang belum pernah ada tersebut akan membuat konsumen di kota tersebut penasaran dan membelinya. UMKM Nuriza Snack mencari beberapa distributor dari luar kota yang dapat mendistribusikan produk keripik hasil produk UMKM ini. Apabila produk keripik dengan varian rasa baru yang belum pernah dijual kompetitor tersebut disukai dan laku oleh masyarakat luar kota, maka UMKM Nuriza Snack memiliki peluang yang bagus di luar kota dan dapat menyaingi kompetitor yang ada. Kebijakan lainnya yaitu dengan menetapkan harga promosi seperti Buy 3 Get 1 dan bundle pricing. Dengan begitu customer akan tertarik dan rela untuk membeli lebih banyak produk. Hal ini juga akan menjadi faktor bertambahnya pendapatan pada UMKM ini.

Implikasi Teoritis pada penelitian ini yaitu perbaikan kebijakan yang disarankan peneliti kepada mitra dengan metode penjelasan terkait perencanaan, produksi, dan pemasaran.

Implikasi Manajerial

Gambar.5 proses Perencanaan, Produksi, dan pemasaran

\begin{tabular}{|c|}
\hline Identifikasi peluang, target pasar, dan tingkat persaingan \\
\hline$\downarrow$ \\
\hline Pemilihan bahan baku pada pemasok \\
\hline$\downarrow$ \\
\hline produksi bahan baku \\
\hline$\downarrow$ \\
\hline pengemasan \\
$\downarrow$ \\
\hline Pemasaran
\end{tabular}

\section{Saran}


Saran yang ingin diberikan kepada UMKM Nuriza Snack yaitu terus melakukan upaya upaya menangani permasalahan didalam manajemen maupun dengan customer dan selalu melakukan inovasi dan evaluasi terhadap produk yang ditawarkan kepada pelanggan agar tercapai sasaran yang diinginkan. Dan diharapkan dengan adanya penelitian ini ,Dan semoga adanya penelitian selanjutnya dapat membantu untuk penyempurnaan artikel sebelumnya.

\section{Ucapan Terima Kasih}

Selesainya pengerjaan artikel ini dikarenakan adanya kerja sama dan bantuan dari pihak terkait. Penulis mengucapkan terima kasih kepada : (1). Tuhan Yang Maha Esa, (2).Bapak Hery Haryanto, S.E., M.M selaku dosen pengajar mata kuliah Teori Ekonomi Mikro, (3).Kepada orang tua dari pihak terkait yang sudah mendukung dan memberikan semangat, serta doa selama proses pengerjaan artikel ini hingga artikel ini selesai.

\section{DAFTAR PUSTAKA}

Assauri, S. (2008). Manajemen Produksi Dan Operasi (ed revisi). Fakultas Ekonomi Universitas Indonesia : JAKARTA., 2008.

Coulthard, Max dan Andrea Howell, and G. C. (1996). Business planning: the key to success (Print book). outh Melbourne: Macmillan Education Australia, 1996. http://www.worldcat.org/oclc/106690297
5

Davenport, T. (1994). Process Innovation: Reengineering Work through Information Technology. In European Journal of Information Systems (Vol. 3, Issue 3). https://doi.org/10.1057/ejis.1994.28

Elisabet, Y. R. (2012). Jurnal Ekonomi Pembangunan. Analisis Efisiensi Dan Produktivitas Tepung Terigu Di indonesia Periode 1998-2008 (ISIC 15321). 10(2), 116-123.

Falahah. (2012). Analisis Dan Perbaikan Proses Bisnis Administrasi Diklat (Studi Kasus Sistem Informasi Diklat XYZ). SemNasIF 2012 UPN "Veteran" Yogyakarta, 2012(30 Juni), 45-51. http://jurnal.upnyk.ac.id/index.php/semn asif/article/view/1077

Kotler, Philip; Armstrong, G. (2008). Prinsipprinsip Pemasaran (Edisi 12.J). Edisi 12.Jilid 1. , Jakarta: Erlangga.

Kotler, Philip, K. L. K. (2007). Manajemen Pemasaran (Edisi 12.J). Jakarta: PT Indeks.

Kotler, P. (1973). Marketing management analysis, planning, and control 4th ed (eBook: Do). Englewood Cliffs, N.J. : Prentice-Hall, C1980.

Small business management : an entrepreneur's guide to success, (1993).

Moekijat. (2000). Manajemen pemasaran. Bandung : Mandar maju.

Ryan, K., Di, C., \& Kudus, K. (2017). Analisis 
Proses Bisnis Usaha Mikro Kecil Menengah

(Umkm) Konveksi Ryan Collection Di

Kabupatan Kudus. Jurnal Administrasi

Bisnis, $\quad 6(1)$, 24-30.

https://doi.org/10.14710/jab.v6i1.16603

Sistaningrum, W. (2002). Manajemen penjualan produk. Kanisius.

Sugiyono, D. (2013). Metode penelitian pendidikan pendekatan kuantitatif, kualitatif dan R\&D. Bandung : Alfabeta. 